\title{
Going Karura
}

\section{Colliding subjectivities and labour struggle in Nairobi's gig economy}

\author{
Gianluca Iazzolino \\ Firoz Lalji Centre for Africa, Department of International Development, LSE \\ Centre of Socio-legal Studies, University of Oxford \\ G.Iazzolino1@1se.ac.uk \\ G.Iazzolino@csls.ox.ac.uk
}

Accepted: 23-Jun-2021

\begin{abstract}
Based on an ethnography of Uber drivers in Nairobi, my article explores practices of contestation of the gig economy taking place both in the digital and physical space of the city. It argues that the labour struggle against the price policies and the control mechanisms of ride-hailing platforms like Uber foreground the tension between a subjectification from above, in which the platforms construct the drivers as independent contractors, and the shaping of subjectivities through the interaction of the drivers with the digital platforms and with one another. It also suggests that, through contestation, as the one catalysed by the call to 'go Karura', logging-off from the app, the workers connect their struggle to a broader critique of processes of exploitation, dependency and subalternity involving the state and international capital. While contributing to the growing literature on the gig economy in low and middle-income countries, my article brings the labour geography scholarship exploring how workers collectively shape economic spaces in conversation with the intellectual tradition of Italian Operaismo (Workerism). In doing so, it highlights the nexus of labour subjectivity and collective agency as mutually constitutive.
\end{abstract}

\section{Introduction}

On the morning of the $2^{\text {nd }}$ July 2018, about a hundred vehicles converged at the main intersections in downtown Nairobi, grounding the rush-hour traffic of the Kenyan capital to a halt. The drivers behind the coordinated action worked in Nairobi's booming ride-hailing sector and had mobilised to protest the fare policies of the two dominant players, the digital platforms Uber and Taxify ${ }^{\mathrm{i}}$. A few Uber and Taxify drivers tried to cross the picket line, but the protesters targeted the strikebreakers' cars, puncturing their tyres and setting at least a vehicle ablaze. The police intervened to tackle the traffic congestion and prevent angry drivers from marching on the Uber head office in the upscale 
Riverfront office block. The images of the protest went viral on social media and were broadcasted during the evening news. The strike lasted nine days and led to dozens of drivers' arrest (Reuters, 2018).

While taking the streets of Nairobi, the digital drivers - as they self-identified - had all uninstalled the apps of Uber and Taxify from their smartphones. As a leader of the Digital Taxi Association of Kenya (DTAK), an organisation that claims to represent over 2,000 digital drivers ${ }^{\mathrm{ii}}$, explained to me a month after the strike, "They [the digital firms] notice us only when we disappear. '"iii In Nairobi's digital drivers' jargon, logging off to become invisible to the platform is called "going Karura", after a forest in Nairobi that occupies a special place in the antagonist geography of the Kenyan capital. In the 1950s, the Karura forest caves served as a hideout for Mau Mau guerrilla fighters waging an insurgency against British colonialists. More recently, in the late 1990s, the forest was the frontline in the battle of the scholar, environmental activist and Nobel Peace laureate Wangari Maathai against the development plans of then-President Daniel Arap Moi.

The interviews on which this article is based revealed the evocative power of the expression 'going Karura'. As I prompted the drivers to reflect on the backstory of the $2^{\text {nd }}$ July protest, the reference to Karura forest conjured up the continuity of colonial, political and corporate dynamics of surveillance and rent-seeking. Vanishing from an in-app map amounted to 'downing the tools' to demand changes to the platform's fare structure. It was also part of a broader self-organising experiment through which the digital drivers sought to make sense of, and redress, the power asymmetries of the fledgling Kenyan gig economy.

This article focuses on Nairobi's digital drivers' experience of gig work to explore the relational and meaning-building processes framing the drivers' strategic use of both the digital and physical space. It is concerned with the following questions: How do the workers' understanding and experience on the 'digital shopfloor' shape the struggle against digital platforms? What kind of subjectivities are produced by this struggle?

By positing labour subjectivity and collective agency as mutually constitutive, I argue that the labour struggle against the price policies and the control mechanisms of ride-hailing platforms foregrounds the tension between a subjectification from above, in which the platforms construct the drivers as independent contractors, and the shaping of subjectivities through the interaction of the 
drivers with the digital platforms and with one another. I also suggest that, through contestation, as the one catalysed by the call to 'go Karura', the workers connect their struggle to a broader critique of processes of exploitation, dependency and subalternity involving the state and international capital. Conceptualising the agency of gig workers thus entails engaging with how the workers, collectively, jam the platform's working while becoming conscious of the "dual value production" (Van Doorn and Badger, 2020), through service provision and data extraction, in which they are involved.

At the empirical level, this article contributes to the growing literature on the gig economy in low and middle-income countries by showing how organisation and mobilisation are entwined to a process through which workers make sense of their role in the Kenyan digital economy. Ride-hailing platforms are among the most conspicuous firms operating in the "physical gig economy" (Heeks, 2017), a sub-category of the broader digital economy in which, like in the case of Uber, workers complete location-specific "work on-demand via app" (De Stefano, 2016). Although digital platforms frame their association to workers as a partnership between equals, media and academic evidence, and the same case study I analyse in this article, suggests that the labour relations in the gig economy are highly contentious (Wood and Lehdonvirta, 2019). These tensions stem from the gap between, on the one hand, the platforms' claims of disintermediation and the emphasis their operators place on supporting the entrepreneurial self of the workers (Purcell and Brook, 2020); on the other, the datadriven commodification of labour-power that constraints workers' agency and compounds their vulnerability to exogenous shocks. Although, at the time of my fieldwork, the overwhelming majority of the participants of my study had a registered account on multiple ride-hailing platforms, in this article I mainly focus on the workers' engagement with one firm in particular, Uber, for three key reasons: it is the most popular ride-hailing platform in Kenya; its market power sets the benchmark for the competitors; and the term Uberization has come to define a business model featuring labour hyperflexibility, algorithmic control and the strategic flouting of local labour regulations (Fleming, 2017).

My contribution has also a theoretical ambition. Addressing the platform work's "theory problem" recently highlighted by Joyce (2020), it builds on the labour geography scholarship exploring how workers collectively shape economic spaces (Herod, 1997) and the embeddedness of labour agency (Coe and Jordhus-Lier, 2011) vis-à-vis the momentous diffusion of digital labour (Anwar and Graham, 
2020). It thus brings this literature in conversation with the intellectual tradition of Italian Operaismo ${ }^{i v}$ (also known in the Anglophone world as Workerism). I primarily draw on the early operaista reflections on the role of technology in reshaping the Marxist relationship between fixed and variable capital (Tronti,1966) and the concept of class composition (Alquati 1975) to explore how workers' struggles reveal the "political implications of the productive action"v (Panzieri, 2020: 92). I also take stock of later operaista hybridisations with post-structuralism (Hardt and Negri, 1994) to explain the emergence of a collective subject subverting and subsuming the production relations in which gig workers are embedded.

This article is divided into two parts. I first tie together the discussions on the gig economy, labour agency, and Operaismo, highlighting the contribution that this latter brings to understanding labour struggles in the digital economy. After explaining my methodology, in the second part I present my case study and discuss the themes emerging from my findings, including the collision between a subjectification from above and below, and the carving of Karura as a space of inquiry and organisation.

\section{Scrutinising the gig economy}

The public and academic conversation around the gig economy is part of a broader effort to grapple with the economic and societal fallout of the collapse of the post-war social contract and the erosion of standard employment relations (SER). Digital platforms foreground the emergence of business models centred on both the extraction of rents from platform-embedded service provision and the production of data as a specific asset class (Sadowski, 2019; Van Doorn and Badger, 2020). A growing academic literature is scrutinising this consolidating landscape of capital accumulation (Woodcock and Graham, 2019). One stream focuses on its macro-dynamics, historicising its emergence (Stanford, 2017; Zwick, 2018), highlighting the obsolescence of existing labour regulations (Aloisi, 2016; Lobel, 2017) and discussing the legal expedients, such as misclassification, enabling digital platforms to exploit regulatory loopholes and formally avoid liability for the workers' welfare (De Stefano, 2016; Shapiro, 2017). Another body of work explores the implications of "techno-normative 
forms of control" (Gandini, 2019: 1041) for the platform workforce based on algorithmic management (Andersson Schwartz, 2017) and datafication (Sadowski, 2019). By brokering connections among multiple parties (Snricek, 2016), digital platforms turn performances, processes, transactions and interactions into data (Ash et al., 2018), enabling algorithmic models to optimise the allocation of resources, identify customer needs and discipline workers (Van Djik et al. 2018; Zuboff, 2019). The platforms' management model (Moore and Joyce, 2020) allows a 'soft' control (Wood et al., 2019; Yeung, 2017) that integrates the remote monitoring of a 'geographically dispersed workforce" (Veen et al. 2019) with customers' feedback, ranking and rating systems (Calo \& Rosenblat, 2017). Yet another stream of research discusses gig workers' conditions (Jamil and Noiseux, 2018; Rosemblat and Stark, 2016) and self-perceptions (Chen, 2017; Peticca-Harris and Al. 2020; Wood et al., 2018), including a sub-focus on the global south with a still limited, but rising, number of case studies of ridehailing platforms ranging from India (Kashiap and Bathia, 2018), to Nigeria (Meagher, 2018), to South Africa (Carmody and Fortuin, 2019; Pollio, 2019). A thread running through this substream is the attention to the instrumental use that digital platforms make of the language of socio-economic inclusion, complicating the relationship of development, technology and entrepreneurship (Graham et al. 2017; Koskinen et al., 2018). Finally, this article directly speaks to the burgeoning scholarship on how gig workers resist and organise, either through legal actions (Joyce et al., 2019), individual tactics to navigate precarity (Attoh et al., 2019; Shibata, 2019) or collective forms of 'structured antagonism' (Wood and Lehdonvirta, 2019) and "digital picketing" (Tassinari and Maccarrone, 2019). With a few exceptions (Anwar and Graham, 2020; Ford and Honan, 2019; Woods and Lehdonvirta, 2019), also this literature has hitherto paid limited attention to the contestation of gig workers in low- and middleincome countries, despite the rising number of digital platforms and the weak or loosely enforced labour laws compounding workers' bargaining power. This bias can be explained with both the greater concentration of digital platforms in rich economies and the fact that the studies on precarious workers' mobilisation largely gravitate around trade unions and formal worker organisations (Rizzo and Atzeni, 2020), while, in the Global South, informal organisations are at the forefront of the contestations (Joyce et al., 2019). 
With its focus on the strategies through which labour manipulates space and engages with capital's spatial fix (Herod, 1998: 5; see also Castree, 2007; Coe and Jordhus-Lier, 2011), labour geography provides a valuable analytical repertoire to examine the mutual shaping of gig worker agency and socio-spatial relations. By delving into the "multiple geographies and temporalities" (Coe and Jordhus-Lier, 2011: 214) of the networks in which workers are embedded, and within which workers' agency is either magnified or constrained, geographers, but also industrial relations and critical management scholars, have explored how workers' power is situated, expressed as resilience, reworking and resistance, according to Cindy Katz (2004)'s influential framework (Anwar ad Graham, 2020; Coe and Jordhus-Lier, 2010; Strauss, 2020), and linked to structure (Wright, 2000) to forge solidarity ties among workers (Fantasia, 1988; Tassinari and Maccarrone, 2019). But while the interest in workers' agency is at the core of labour geography, inspiring recent works, including in this journal, that have explored the agentic practices of digital workers (Anwar and Graham, 2019; Wells et al. 2020), the notion of subjectivity has been mainly the remit of human geographers, brought into conversation with the 'agent' (Poon and Cheong, 2009) in Foucaldian philosophical arenas (Read, 2009), as “constituted by 'disciplinary practices' and 'relations of power'” (Foucault, 1979).

Rogaly (2009) points out that, at its very premises, labour geography has overlooked Harvey's (2006) discussion of how Lefebvre's 'spaces of representation' shape worker subjectivities. The influence of these spaces of representation upon the material space clearly emerges as the reference to the Karura forest, steeped in a history of anticolonial resistance, becomes the call to digital invisibility among Nairobi's digital drivers. Drawing on Burawoy, Purcell and Brook (2020) situate the emergency of subjectivity "within-against the relations of production." (5) Importantly for this article, mapping the different geographical imaginations of the subject, Pile (2009) draws attention to subjectivity "as a process through which individuals make sense - unconsciously, emotionally, psychologically - of the shifting and colliding worlds that they live in" (213). The collision between narratives of entrepreneurship and the control that characterises their experience of gig work influences the process through which digital drivers' subjectivities and agency emerge. 
The most fruitful attempts to link the construction of subjectivity and the mobilisation of agency can be found withing the theoretical discussion building upon Marx's reflections on the labour process. I want to acknowledge in particular the contribution of the operaisti, in Wright's (2014) words, at "the forefront of those in the West who, in exploring what Marx had once called 'the hidden abode of production', rediscovered the labour process as the contested terrain of managerial prerogatives and workers' resistance to exploitation" (369). The image of the 'hidden abode of production' is featured in Marx's analysis of the production of surplus-value and has recently been discussed with reference to the digital economy's “dual value production" (Van Doorn and Badger, 2020) generated by service provision and data extraction, and the reproduction of exploitative employment conditions through managerial logics that are far from view, although not 'black-boxed' (Moore and Joyce, 2019).

There has been renewed interest in the speculations of the 1960s Italian operaisti for approaching the composition of the labour force in the digital economy (Cant 2019; Delfanti, 2021; Woodcock 2021). More a set of concepts and methodologies than a consistent theory, the Operaismo project entered the intellectual arena in 1961 with the launch of the journal "Quaderni Rossi" (Red Notebooks) by a group of leftist thinkers - including Raniero Panzieri, Mario Tronti, Romano Alquati and Toni Negri -to carve a space for a heterodox reading of Marx, in opposition to the dominant Gramscian interpretation of the Italian Communist and Socialist Parties. Despite ending with the closure of Classe operaia in 1967, the operaista experience left a long-lasting legacy on the late 1960s and 1970s autonomism. The historian and co-founder of Classe operaia, Sergio Bologna, (2014) explains this longevity with the operaista's commitment to "develop a theory of liberation in the post-Fordist society". Over the years, Operaismo's staple concepts, such as Alquati's notion of class composition or Tronti's 'social factory', have proven ductile enough to find application to the analysis of post-colonial political economies (Mezzadra, 2008) or the socio-economic and geopolitical transformations induced by the crisis of Taylorism and the rise of the knowledge economy (Hardt and Negri, 2000). More recently, Woodcock (2021) have called for the development of a 'digital workerist' agenda that locates the workers' experience in the platformised workplace at the centre of the capitalist critique.

Under the influence of Panzieri, the operaisti highlighted the nexus between the workers' struggle and technological innovation, suggesting that capitalist transformations are driven by the 
constant pressure to respond to labour mobilisation. Panzieri drew attention to the way technology, as an emanation of the capitalist rationality, reconfigures both the production and valorisation processes. In his commentaries to Marx's "Fragment on the machines", from the Grundrisse, and the first and third books of the Capital, Panzieri examines the significance of technology in capitalist planning for both maximising the surplus value extracted from labour and bypassing the limitations imposed by regulators to its extensive exploitation. His conclusions are primarily political because they "turn on its head the broad social consensus on the neutrality of technology" (Cengia, 2020: 34). They are nevertheless of theoretical relevance when applied to the analysis of the tensions arising from managing workers in the gig economy. In the case of Uber, for instance, the algorithmic management which platform executives invoke to justify policy changes that affect drivers' income and wellbeing resonates with Panzieri's (2020) observation that "technological innovations amplify the despotic tendencies of capitalism, disguising the capitalist rationality as a technical necessity"(92). His Marx-inspired conclusion that surveillance is at the essence of capitalism shows data-powered surveillance capitalism not as capitalism 'gone rogue', a creation of tech giants, pace Zuboff (2019), but as an intrinsically despotic system that scales up its monitoring potential through data extraction.

Shying away from a priori categories, the operaisti were also concerned with probing the contours of the working class, an 'unknown continent' in Tronti's words (1964), animated by the convergence and collision of different subjectivities and interests, all sharing the same opposition to the management. The coalescence around specific production relations is the precondition to becoming a political subject taking shape through, and in, the struggle. Alquati (1975) coined the expression 'class composition' to describe this process, divided into two steps -technical and political - linked by a political 'leap' leading to the emergence of an antagonistic force.

The post-or late Operaismo of Toni Negri (1994), influenced by Deleuze and Guattari, drops the notion of class composition in favour of organised autonomy. Negri flips the relation of subsumption between variable labour and fixed capital to suggest the appropriation of this latter by the former. It is through this capture, and an increasingly intense antagonism, that subjectivity becomes the site of resistance to the pressure of neoliberal capital (Toscano 2009). Drawing on Marx's (1887) notion of 'living labour', or "labour-power in action [that] seize upon these things (the machine) and rouse them 
from their death-sleep, change them from mere possible use-values into real and effective ones" (130; see also Lubin-Levy and Shvarts, 2016), Hardt and Negri (1994), argue that the 'fire of labour' ignited by living labour to revive labour's dead capital is also a focus of struggle, "a seed that lies waiting under the snow, or more accurately, the life force always already active in the dynamic networks of cooperation, in the production and reproduction of society, that courses in and out of the time posed by capital.” (1)

Methodologically, the operaisti explored the workers' experience through the process of conricerca (co-inquiry) (Alquati, 2000), which challenged the power geometry between the researchers and the subjects of investigation. This approach was based on a tradition of worker's inquiry tracing back to Marx (Woodcock, 2014), and aiming to capture the political logic emerging from "the workingclass viewpoint" (Haider and Mohandesi, 2013). Because of time constraints and a limited engagement with the participants to the investigation due to the outbreak of the COVID 19 pandemic, the study behind this article was not fully conducted in the spirit of conricerca. However, it was informed by two tenets of conricerca: first, the concern of grappling with the workers' perspective on the struggle, such as it was expressed in the construction of Karura as a space of (self-)inquiry and organisation; second, the awareness of the asymmetry between researcher and informants, and the risk that it could be exacerbated when conflated with the roles of riders and drivers.

\section{Methodology}

This article draws on evidence collected in Nairobi between 2018 and 2019. It builds upon observation of drivers' meetings, in-depth interviews with digital drivers (55), executives of ride-hailing companies (2), union activists (2) and driver organisation leaders (5). The interviews were conducted face-to-face over four months in 2018 and one month in autumn 2019. Follow-up interviews with 15 of the drivers already met in person were carried out over WhatsApp in the first half of 2020 when the conversations inevitably centred on the health and economic concerns stirred by the COVID-19 pandemic. The repercussions of the pandemic on the digital drivers' experience will not be discussed in this article because they are the topic of research still in progress. 
In summer 2018, before the strike described at the beginning of this article, I contacted an initial group of drivers $(n=10)$ through trip requests via the Uber and Taxify apps. I was particularly wary of the risk that the tacit threat of a bad rating could coerce them into consenting to my request for an interview, a concern shared by most ethnographers of the gig economy (Anwar and Graham, 2021; Rosenblat, 2018; Wells et al., 2021). During the trips, I did not disclose either my role or the purpose of my study. I did not conduct interviews while travelling, but I only asked for their mobile number near the end of the journey. I contacted them a few hours 6 EPA: Economy and Space 0(0) later to ask for an interview outside of their working hours to avoid conflating my role as a researcher and customer.

The number of drivers' and leaders' contacts snowballed. I approached digital drivers in car washes, asking for their availability for an interview. I gained access to more drivers through the Public Transport Operators Union (PUTON) leaders and the founders of Beba Beba, a cooperative platform established by former Uber drivers. Local executives of Uber and Little Cab, another ridehailing firm, proved surprisingly open to my questions, while local policymakers did not return my requests. While executives of ride-hailing firms gave their consent to speak on the record, most drivers felt uncomfortable in front of my recording device. The title of this article, 'going Karura', was an effective reflection trigger during the interviews. Once I learned from a driver about the expression, I was intrigued to investigate its origin. My quest for the roots of this saying, however, proved quixotic. Although the expression was very popular, no one could pin down how it came into being. However, when asked about its meaning, the drivers linked the expression to a cartography of contestation that traces back to colonial times, when the Karura forest gave shelter to Mau Mau guerrilla fighters. Some of them recalled the centrality of the forest in the struggle of Wangari Maathai's Green Belt movement against Moi's government's plan to turn the protected area into a golf course. The interpretation of Karura as a space of contestation did not resonate with all the participants of my study, but I noticed a correlation between the level of engagement within the driver associations and the adoption of anticolonial rhetoric.

The remainder of my article delves into the case study, first describing how the relationship between Uber and its drivers in Nairobi has evolved until the strike which I have sketched above and then drawing insights from my findings. 


\section{"We can see everything"}

Uber launched its operation in Kenya in 2015. The ride-hailing platform framed its role as "covering the last mile" in the capital's sprawling and unequal urban landscape, shaped by the legacy of colonial urban segregation (Makachia, 2011) and a pro-private car bias (Klopp, 2012). Operating the Kenyan market from Amsterdam, where it has established a subsidiary, Uber International C.V., to benefit from Dutch corporate-friendly policies, Uber deployed its blueprint business model, charging a $25 \%$ commission and setting fares based on the kilometrage and the product offered. The platform promised to render visible a transport sector largely perceived by foreigners as unsafe and unreliable. A massive marketing campaign targeted an ever-expanding segment of tech-savvy, cosmopolitan Kenyans and foreigners, eager to rely on a well-known brand, using a familiar mobile interface, and looking for a safe way of moving across the city. Uber positioned itself as the efficient and affordable infrastructure of Nairobi's Silicon Savannah, a landscape of start-ups, business incubators and regional headquarters of foreign tech corporations informed by investments in connectivity infrastructures and inflows of venture capitals (Graham and Mann, 2013).

As a recruitment strategy, the firm poached high-end taxi companies through events and referrals. It offered an enticing rate of $60 \mathrm{KSh}(0.50 \mathrm{GBP})$ per $\mathrm{Km}$, but only the drivers of vehicles with at least $1300 \mathrm{cc}$ and no older than three years were eligible to register on the platform. Many aspirant drivers got into debt to purchase a car with these requirements, borrowing from banks or cooperatives, provided that they had a credit history. Those lacking collaterals resorted to resourceful individuals who leased vehicles for around 2,000 KSh (18 GBP) a day. Uber allowed car owners and drivers to share an Uber account, but all card payments were linked to the bank account of the owner, who would then pay the driver. The drivers were also required to obtain a certificate of good conduct, a private service vehicle (PSV) stamp, a licence to play music, and car insurance, for a total cost of around 50,000 KSh (300 GBP) per year. Despite this burdensome investment, in the first 17 months, a thousand drivers joined the platform

In early 2016, after driving a German-owned ride-hailing firm, Go Taxi, out of the Kenyan market, Uber experienced its first backlash from private taxi drivers, with incidents in which cars were 
torched and its drivers were stabbed (Guardian, 2016). To quell these tensions, Uber launched a campaign to attract taxi drivers by brokering loans from Barclay's Bank at a negotiated rate to purchase vehicles fitting the platform's requirements. As a result of the vehicle financing scheme, the pool of drivers dramatically expanded. Moreover, the programme incentivised card payments because car owners were more willing to get paid digitally, thus facilitating the lease's repayment to the bank and Uber commission.

During the first years, the high demand, fuelled by incentives for drivers and riders, and the limited supply guaranteed good profits. The workforce's growth led to market saturation, resulting in a drop of the number of calls per driver. Still, Uber increased dramatically its pool of data, through which the platform was able to monitor the drivers' behaviour and ensure that their driving and customer service skills would be aligned with the firm's standards. It is important to point out that transport provision is just the most conspicuous side of the dual value production model (Van Doorn ad Badger, 2020) driving Uber expansion. As an executive told me in an interview, the corporation aspires to become "the Amazon of mobility" - a reference to another behemoth of the digital economy - meaning that "from being a transport provider, Uber is becoming a mobility platform" ${ }^{\text {"vi }}$ The same executive stressed that, despite reshaping urban mobility, Uber is a data company, not a transport company. This distinction is crucial to Uber's business model, because it screens the company from the oversight of national labour departments. But it is also a reminder that dataveillance is at the core of Uber's business. As the Uber executive told me, "We can see everything. We can monitor the drivers through the phone - when they accelerate, take a corner too fast, brake too roughly ${ }^{\text {vii } . " T h e ~ t e n s i o n ~ b e t w e e n ~ t h e ~ d a t a-d r i v e n ~}$ commodification of the workers' labour and the narratives of prosperity and independence that Uber initially mobilised to build its workforce exacerbated the digital drivers' grievances when the escalating competition in the city's ride-hailing market precipitated a race to the bottom. In July 2016, Taxify, an Estonian ride-hailing company, entered the fray with its product, Taxify Go, seeking to outprice Uber by charging drivers $15 \%$ commission and setting a fare of $40 \mathrm{KSh} / \mathrm{Km}(0.27 \mathrm{GBP})$. Uber responded by lowering its fares first to $35 \mathrm{KSh} / \mathrm{Km}(0.23 \mathrm{GBP})$ and then to $33 \mathrm{KSh} / \mathrm{Km}(0.22 \mathrm{GBP})$. Combined with a spike in fuel price, this price drop significantly eroded the drivers' earnings. Full-time digital drivers were forced to work longer hours, even sleeping in their cars ${ }^{\text {viii }}$, to meet targets. Then, in January 2018 , 
Uber introduced a 10-hour driving time limit. The drivers were automatically logged off after 10 hours on the platform and were not assigned more trips before six hours had passed. Many drivers reacted to the 10 hours cut-off time by logging off when stuck in traffic, or refusing the request on the app and agreeing with the customers by phone. As independent contractors, they felt that they were entitled to turn down a ride request, which they often did when the dispatch to the pickup point was too distant, or the destination would take them to unsafe areas, but Uber often targeted them with messages hinting that a high refusal rate would affect future assignments.

In March 2018, Uber reduced its fares to $27 \mathrm{KSh} / \mathrm{Km}$ (0.18 GBP). This reduction coincided with a new peak in fuel price to $118 \mathrm{KSh}$ a litre $(0.79 \mathrm{GBP})$. The drivers were aggrieved to see their profit margins eroded. Particularly incensed were the drivers leasing a car who needed to reach a daily target for not incurring a loss. Others had financed their car's purchase through a loan and now found themselves increasingly striving to service the debt. The relations between drivers and partners soured as the drivers struggled to turn a profit or were paid late by the partners who had received the payments on their accounts.

\section{Strike!}

As working conditions were deteriorating and income was falling, Uber drivers traded experiences and views in the 'interstitial spaces' (Brighenti, 2013) of the city - petrol stations, car washes and shopping malls parking. - . These discussions continued and intensified in neighbourhoodbased groups, which the drivers referred to as 'the zones', orbiting around specific areas of Nairobi and led by charismatic leaders. One of these leaders, mentioned by several participants of the study, was known as 'Kim of Eastlands', from the name of an area of Nairobi located around the city's Main Industrial Area, a suburb often featured in the media because of crime and insecurity but steeped in a long history of worker smobilisation ${ }^{\mathrm{ix}}$. Another driver, known as Mkombozi, leveraged his popularity to launch Beba Beba, a driver cooperative that mimicked Uber's model. These grassroots organisations led forms of coordinated insubordination, ranging from sending Uber similar messages reminding the 
firms that the drivers were independent contractors when the platform hid the customers' contact number, to accepting trip requests but not moving.

As observed in other studies of digital drivers' mobilisation (Chen, 2017), this conversation took place both in the streets and online. The drivers drew on insights they derived from their communication with family and friends in the diaspora. For instance, George, a full-time Uber driver, compared his own experience with his brother's, working for Uber in London.

There it makes sense because most people have a stable job and they can afford to drive for Uber in their spare time... Here it cannot work with these fares because there are no jobs and people are desperate to take on whatever comes along. ${ }^{x}$

Another driver, Peter, remarked that

Drivers in Nairobi have additional costs than the ones in Europe or America because here the roads are in very bad conditions and our cars need more maintenance ${ }^{x i}$.

Dan, a leader of DTAK, drew on the example of one of his brothers in the diaspora, with whom he compared their respective experiences on the platform.

"I often speak to my brother in London. He also works for Uber, but he earns good money and has several jobs on the side. He also gets more respect from his customers. Here, they believe we're Uber's employees ${ }^{\text {xii }}$.

Through interactions with his brother working for Uber in London, he connected his platform gig to the looming transformations that would have made him, and the other drivers, redundant.

In a few years, Uber won't need us [drivers]. We're just collecting data for them, for their driverless cars" "xii

Echoing an awareness that Attoh et al. (2019) have found among digital drivers in Washington, DC, Dan had shared his concerns with his fellow drivers, turning the inquiry over Uber's value production into a reflection on both their position in this process and the dependency of their country on foreign corporations' investments. References to the government's inaction seeped into these selfinquiry practices as drivers looked at the protests of Uber drivers outside of Kenya. While in the US, UK and India drivers had sometimes succeeded in prompting city authorities to intervene in the disputes, in Kenya, some argued, this had not happened yet because "the government is in bed with Uber"xiv . These discussions were an opportunity to exchange rumours about the connivance between the Kenyan elite and Uber. ${ }^{\text {xv" }}$ These unverifiable hearsays reflected a broader distrust towards political 
leaders and resonated with Scott's (1985) view of gossip as a weapon of the weak to contest the "public transcripts" of the power.

Neighbourhood-based groups provided delegates to digital driver organisations, featuring elected leaders and a management structure, and a communication strategy through social media, mainly Whatsapp, to get their messages across, coordinate collective actions and exchange information. In 2018, representatives of the Public Transport Operators' Union (PUTON), a Kenyan member of the International Transport Workers Federation (ITF), met with the digital driver organisations, making a case for unionising. Together with the Digital Taxi Forum (DTF), an umbrella organisation established to further the interests of digital drivers, PUTON strove to take the lead of the mobilisation, reaching out to national policymakers to discuss how to regulate the ride-hailing sector ${ }^{\text {xvi }}$. However, similarly to the spontaneous shopfloor protests that fascinated the Italian operaisti, the union failed to lead the mobilisation as the drivers' loyalty mainly rested with their community-based groups.

Thus, during the July 2018 strike with which I opened this article, the instruction to go Karura started from these neighbourhood associations. Their members controlled the picket line, leveraging the "dependence of the city on the continuous circulation and flow of people and commodities" (Rizzo and Atzeni, 2020: 4) to turn the urban spaces into a 'battlefield' (ibid.). The protest brought to the fore the diversity of interests and the different levels of dependence on the digital drivers' ride-hailing platforms. Some Uber drivers who were working for Uber part-time and were not wholly dependent upon the platforms had generally mistrusted all digital drivers' associations. Even if complaining about the falling rates, they decided not to join the strike. Considering the protest leaders as "troublemakers with their own agenda"xvii, many of these drivers used expedients to cross the picket line, such as driving old or unwashed cars that would not be associated with Uber.

At the end of the protest, PUTON brokered a meeting between a delegation of drivers, the representatives of the leading ride-hailing platform and the minister of transport, but, besides a generic commitment to improving the workers' conditions, the non-binding memorandum of understanding (MoU) signed by the parties failed to mention a minimum fare, as requested by the drivers' organisations. The disappointing - for the strikers - outcome of the protest undermined most digital drivers' already fragile confidence in the unions. Overall, the mobilisation's failure was attributed 
mainly by the drivers to a lack of political support and a fragmented leadership, with the leaders of different digital driver groups accusing each other of backstabbing the workers for their self-interest. Following the arrest of dozens of protesters during the July 2018 strike, Little Cab, a ride-hailing platform launched by Craft Silicon, a Nairobi-based tech firm, in partnership with Safaricom, Kenya's largest telecom, offered digital driver organisations 50,000 KSh (300 GBP) to pay for the legal fees of the detained drivers ${ }^{\mathrm{x} v i i i}$. Moreover, Little Cab started co-opting the leaders of the taxi grassroots organisations as recruiters. Casting itself as a genuinely Kenyan company, Little Cab tried to lure drivers with a $15 \%$ commission and a fare of $40 \mathrm{Sh} / \mathrm{Km}$, free data bundle and the possibility to receive payments on the mobile money platform M-Pesa at no additional cost. At the time of my data collection, drivers were torn between the interest towards Little cab and the awareness of being used as pawns in a corporate war.

\section{Discussion}

I have hitherto described Uber's trajectory in Nairobi as drivers responded to the gradual deterioration of their working conditions by simultaneously questioning the firm's business model, resting on the capture of value from both rent and data extraction, and organising into loosely structured formations that articulate the struggle. The starting point for this struggle, as the operaisti pointed out, "are material needs that have to be satisfied" (Potere Operaio, n.d. in Wright, 2012). However, as I have mentioned, a fluid archipelago of community associations, and their online extensions, carved Karura as a space of inquiry and contestation. At the centre of this inquiry was the platform's subjectification from above. The tech giant framed visibility as discoverability, offering aspirant drivers the possibility to be put "on the map" and stressing greater profits and autonomy, producing, distributing and organising social relations and subjects "in such a way as to facilitate the (re)production of capitalism itself" (Böhm and Land, 2012: 225). The interaction with Uber in the datafied space of the platform and among the drivers off-grid, in Karura, revealed the tension between a "regime of visibility [connected] 
to the notion of empowerment" and the sense of disempowerment derived from "ubiquitous computing with increased deployment of surveillance technologies" (Bucher, 2012: 1165).

The hiatus between discourses 'from above' of digital entrepreneurship and inclusion and collective narratives of exploitation was brought to sharp relief by Uber's response to the workers' tactics to offset the falling income from the platform work when the race to the bottom for the dominance of Nairobi's ride-hailing market intensified. Through subsequent updates, Uber concealed both the driver and the passenger's phone numbers and blocked direct communication between the two parties. The platform also stopped showing the driver the destination of the rider and hid the form of payment, whether by cash or by card, as many drivers, often at the end of the week, tended to refuse card payments because they needed cash to refuel. The operaista notion of technological despotism highlights the significance of asymmetric visibility as the strategy with which, "through technology, the capital constantly struggles against the workers' insubordination" (Panzieri, 2020: 83). The operaisti viewed labour as the very driver of capitalist transformation as it forced capital to develop increasingly tight forms of control through the expansion of the fixed capital. In operaista terms, datafication and algorithmic management - 'the machine', or the fixed capital - constrain, and commodify, the variable capital-labour, revealing "the need to control a growing workforce, and therefore the rising power of resistance of the workers" (52).

Uber's policing of the service relationship between the drivers and the customers added to the customers' interiorisation of Uber's misclassification, which emerged when, as most participants to my study complained, the customers treated them not as the entrepreneurs that the drivers were told they are but as Uber's employees. It is through the sharing of these experiences that Uber workers coalesced around the challenge to reconcile discourses of empowerment through datafication and the daily experience of algorithmic management and control, and to make sense of the "meanings attached to the labour process and the interactions that occur during the labour process", as Purcell and Brook (2020) suggest, pointing out that "meaning, or fulfilment, is derived from the interaction with the app rather than from labour itself." (10) Furthermore, the awareness of the platform's disempowering monitoring mapped onto a broader narrative, widespread among the members of drivers' organisations, that stressed the continuity between colonial and corporate logics of extraction (Couldry and Mejas, 2018; 
Mezzadra and Neilson, 2013; Ricaurte, 2019). In community meetings and roadside barazas, the Swahili word for gathering in which political or social topics are discussed, Karura started taking shape as the drivers, in a conricerca spirit, shared their subjective experiences to elaborate on the link between the colonial and the data gaze (Kotliar, 2020).

As George, a disgruntled driver, put it bluntly:

"All this tech around us... it's not for us. Foreign companies here are just using us. This is colonialism all over again., "xix

This "coconstruction of new critical understandings of the self by the collective worker" (Purcell and Brook, 2020: 8) draws material from a spatio-temporal repertoire of contestation rooted in the historical liberation struggle (with reference to the Karura forest) but also to the marginal spaces of the Kenyan capital, hence the centrality of Eastland's driver groups in leading the protest. It is helpful to remind here the operaista concept of class composition, articulated into a technical composition - or the materiality of labour-power as structured by the social relations of production - and the political composition - in which workers self-organise and engage in the labour struggle. The composition of the working class, or the way the working class composes itself (Mohandesi, 2013: 85), reflects contextual variations in the forms of the workers' struggle "because the concrete labour-process and therefore the material form of exploitation differs" (Kolinko, 2001, cit. in Mohandesi, 2013). In his study of the role of the Kenyan strike movement colonial in accelerating the transformation and the demise of the colonial economy, Zeleza (1992) emphasises the role of community associations in providing a space in which the workers shared experiences of exploitation and reflected on their role in the productive process. Similarly, the spontaneous drivers' organisations built upon self-help groups initially established to address practical concerns, such as providing mutual support. Featuring a distinct ethnic connotation, these associations performed cultural and social reproduction functions, revolving, for instance, around saving groups to support the members in need, or burial societies, collecting money to pay for the funeral expenses of the drivers who had died on the job ${ }^{\mathrm{xx}}$. These neighbourhood-based associations embodied the operaista social factory in which, as Verónica Gago (2015) remarked regarding Argentinian informal workers' networks, "the community is one of the elements incorporated into the sphere of valorisation when this includes a set of connections, affects, and forms of cooperation 
that expand and reclassify a form of production that is no longer confined within the factory walls." (89) The drivers' strong allegiance to these associations contributed to undermining PUTON's efforts to mobilise the workers. Instead, the grassroots organisations at the centre of the struggle were the crucible of subjectivities which, as Gago suggests, "always have to do with practices" (12). These drivers' associations encapsulated the above mentioned "seed that lies waiting under the snow". The ephemeral alliance between Little Cab and the drivers' leaders can be seen as an expression of the living labour re-subsuming the machine - the app-platform assemblage - that operationalises platform capitalist despotism. This is done tactically by disrupting the monitoring of data flows and cars underpinning Uber's production of value; strategically, by shaping Karura as a space of inquiry and organisation. The relationship between space and labour goes two ways: as labour manipulates urban spaces, the city contributes to creating workers subjectivities. The unsafe, lunpen-space of Nairobi's Eastlands is not only the pool of a hustling reserve army for digital platforms, rife with relationships of power, often brutally expressed, but also the counterpoint to the smart city poised between inclusion and surveillance.

\section{Conclusion}

In this paper, I have suggested that the confrontation between Uber and its Kenyan drivers foregrounds the tensions encapsulated in digital platforms as both a promise of incorporation in the digital economy and an expression of power relations. While digital platforms recast their business operations in terms of job creation, 'going Karura' reminds us that this type of inclusion, made possible through digitisation and datafication, is a political project and, as such, in Gramscian terms, an ideological frontline. If, as Mezzadra and Neilson (2013) argue, "the production of subjectivity is a terrain of struggle in the actual workings of capitalism" (10), grappling with the internal dynamics of gig workers' organisation entails understanding how this production is discursively and materially contested and disrupted. Going Karura echoes, in a different time and space, the salto della scocca, the voluntary omission of a piece on the assembly line, a sabotage practice that captured the operaista 
political imagination. Digital invisibility is the counter to the capital's hidden abode, where workers disrupt the two-pronged mechanisms of value creation both blocking the transport service and stopping the production of data. Going Karura emerges as an expression of labour-power through which workers reclaim the agency stealthy eroded by the platform's dataveillance.

The gig economy landscape is punctuated by setbacks, as recently shown by the approval of Proposition 22 in California, which denies labour protection to ride-hailing workers and whose campaign laid bare the vast power imbalance between digital platforms and workers. Further research is required to understand how this power is both deployed and resisted across different latitudes, particularly as the current COVID-19 pandemic is compounding the precarity of digital drivers.

\section{Acknowledgements}

Previous drafts of this paper have been presented in the LSE Anthropology of Economy/Inclusive Economies seminar, organised by professor Deborah James, at LSE cities seminar, LSE International Development department staff seminar and Development Studies Association Conference, Open University. The author is grateful to all those who have contributed to improving this paper with their questions, encouragement and doubts. In particular, the author would like to thank Kate Meagher, Laura Mann, Shirin Madon, Marion Ouma, Silvia Masiero and Michael Kimani for their feedback. A special thanks goes to all the workers and activists who have shared their experience with me.

\section{Funding}

The author disclosed receipt of the following financial support for the research, authorship and/or publication of this article: This work was supported by LSE Cities Seed Grant; Economic and Social Research Council (grant number ES/P009603/1); UKRI GCRF DIDA (grant number EP/T030127/1) 


\section{References}

Alquati, R. (1993) Per fare conricerca. Milano: Calusca.

Alquati, R. (1975) Sulla FIAT e altri scritti. Milano: Feltrinelli

Andersson Schwarz, J. (2017) 'Platform Logic: An Interdisciplinary Approach to the PlatformBased Economy', Policy and Internet, 9(4): 374-394.

Anwar, M. A. and Graham, M. (2019) 'Hidden transcripts of the gig economy: labour agency and the new art of resistance among African gig workers', Environment and Planning A, 0(0): 1-23.

Anwar, M. A. and Graham, M. (2020) 'Digital labour at economic margins: African workers and the global information economy', Review of African Political Economy, 1-12

Ash, J., Kitchin, R. and Leszczynski, A. (2018) 'Digital turn, digital geographies?', Progress in Human Geography, 42(1): 25-43.

Attoh, K., Wells, K. and Cullen, D. (2019) “"We're building their data”: Labour, alienation, and idiocy in the smart city', Environment and Planning D: Society and Space, 0(0): 1-18.

Beer, D., (2016) Metric power. London: Palgrave.

Böhm S. and Land C. (2012) The new 'hidden abode': Reflections on value and labour in the new economy. The Sociological Review 60(2): 217-240.

Bologna, S. (2014) 'Come il patrimonio teorico dell'operaismo italiano è servito a comprendere la realtà del lavoro postfordista.' Available at http://effimera.org/come-il-patrimonio-teoricodelloperaismo-italiano-e-servito-a-comprendere-la-realta-del-lavoro-postfordista-di-sergio-bologna/

Brighenti, A. (2013) Introduction. In: Brighenti, AM (ed.) Urban Interstices: The Aesthetics and the Politics of the In-between. Aldershot: Ashgate, $\mathrm{xv}-\mathrm{xxiii}$.

Bucher, T. (2012). 'Want to be on the top? Algorithmic power and the threat of invisibility on Facebook', New Media and Society, 14(7): 1164-1180.

Calo, R. and A. Rosenblat (2017), 'The Taking Economy: Uber, Information, and Power', Columbia Law Review 117, 1623-1690.

Cant, Callum. 2019. Riding for Deliveroo: Resistance in the New Economy. Cambridge: Polity. Carmody, P. and A. Fortuin. 2019. "Ride-sharing", virtual capital and impacts on labor in Cape Town, South Africa." African Geographical Review 38, 196-208. 
Castree N. (2007) Labour geography: A work in progress. International Journal of Urban and Regional Research 31(4): 853-862.

Cengia, A. (2020) Introduzione. Panzieri: politica, etica e teoria come coordinate dell'azione. In Panzieri, R. Il lavoro e le macchine. Critica dell'uso capitalistico della tecnologia. A cura di Cengia, A. Ombre Corte: Verona.

Chen, J. Y. (2017). 'Thrown under the bus and outrunning it! The logic of Didi and taxi drivers' labour and activism in the on-demand economy', New Media \& Society, 20(8): 2691-2711

Coe, N. M. and Jordhus-Lier, D. C. (2011) 'Constrained agency? Re-evaluating the geographies of labour', Progress in Human Geography, 35(2): 211-233.

Couldry, N. and Mejias, U. A. (2018). 'Data Colonialism: Rethinking Big Data's Relation to the Contemporary Subject', Television and New Media, 20(4): 336-349.

Delfanti, A. (2021) 'Machinic dispossession and augmented despotism: Digital work in an Amazon warehouse', New Media and Society, 23(1): 39-55.

De Stefano, V. (2016) Introduction: crowdsourcing, the gig-economy and the law. Comparative Labour Law \& Policy Journal 37(3): 461-470.

Fantasia R. (1988) Cultures of Solidarity. Berkeley, CA: University of California Press.

Fleming, P. (2017) 'The Human Capital Hoax: Work, Debt and Insecurity in the Era of Uberization', Organization Studies, 38(5): 691-709.

Foucault, M. (1979) The History of Sexuality, Volume 1: An Introduction, London: Allen Lane.

Gago, V. (2015) Neoliberalism from Below: Popular Pragmatics and Baroque Economies. Durham, NC: Duke University Press

Gandini, A. (2019) 'Labour process theory and the gig economy', Human Relations, 72(6): 10391056.

Graham, M. and Mann, L. (2013) 'Imagining a Silicon Savannah? Technological and Conveptual Connectivity in Kenya's BPO and Software Development Sectors', EJISDC, 56(2): 1-19.

Graham, M., Hjorth, I. and Lehdonvirta, V. (2017) 'Digital labour and development: impacts of global digital labour platforms and the gig economy on worker livelihoods', Transfer, 23(2), 135-162. 
Guardian (2016) Second Uber taxi set on fire in Kenya amid competition row. 23 March. Available at: https://www.theguardian.com/world/2016/mar/23/uber-taxi-set-on-fire-nairobi-kenyaindustry-dispute

Haider, A. and Mohandesi, S. (2013) Workers' Inquiry: A Genealogy. 27 September. Available at: https://viewpointmag.com/2013/09/27/workers-inquiry-a-genealogy/

Hardt, M. and Negri, A. (1994) Labor of Dionysus: A Critique of the State-Form. Minneapolis: University of Minnesota Press.

Harvey, D. (2006). Spaces of global capitalism: towards a theory of uneven geographical development. London: Verso.

Heeks, R. (2017). Digital Economy and Digital Labour Terminology: Making Sense of the "Gig Economy”, “Online Labour”, “Crowd Work”, "Microwork”, "Platform Labour”, Etc. Development Informatics, Working Paper no.70. Manchester, UK: University of Manchester.

Herod, A. (1997) From a geography of labor to a labor geography: rethinking conceptions of labor in economic geography. Antipode, 29: 1-31.

Ford, M. and Honan, V. (2019) 'The limits of mutual aid_Emerging forms of collectivity among app-based transport workers in Indonesia', Journal of Industrial Relations, 61(4): 528-548.

Jamil, R. and Noiseux, Y. (2018) 'Shake that moneymaker: insights from Montreal's Uber drivers', Interventions économiques, 60: 0-30.

Joyce, S. (2020) Rediscovering the cash nexus, again: subsumption and the labour-capital rela tion in platform work. Capital and Class, 1-12.

Lobel, O. (2017) 'The gig economy \& the future of employment and labor law', University of San Francisco Law Review, 51(1): 51-74.

Lubin-Levy, J. and Shvarts, A. (2016) Living Labor: Marxism and Performance Studies, Women \& Performance: a journal of feminist theory, 26 (2-3): 115-121

Kashyap, R. and Bhatia, A. (2018) 'Taxi Drivers and Taxidars: A Case Study of Uber and Ola in Delhi’, Journal of Developing Societies, 34(2): 169-194.

Katz, C. (2004) Growing up Global. Minneapolis: University of Minnesota Press. 
Klopp, J. M. (2012) 'Towards a Political Economy of Transportation Policy and Practice in Nairobi', Urban Forum (1372): 1-21.

Koskinen, K., Bonina, C. and Eaton, B. (2018) Development Implications of Digital Economies Digital Platforms in the Global South: Foundations and Research Agenda. Paper n. 8. Development Informatics, Working Paper no.70. Manchester, UK: University of Manchester.

Kotliar, D.M. (2020) Data orientalism: on the algorithmic construction of the non-Western other. Theory and Society.

Makachia, P.A. (2011) 'City, Culture and Society Evolution of urban housing strategies and dweller-initiated transformations in Nairobi', City, Culture and Society. 2(4): 219-234.

Marx, K. (1887) Capital: A Critique of Political Economy, Volume 1. Ed. F. Engels, trans. Samuel Moore and Edward Aveling. Moscow: Progress Publishers. Available at: www.marxists.org/archive/marx/works/download/pdf/Capital-Volume-I.pdf

Meagher, K. (2018) 'Rewiring the Social Contract: Digital Taxis and Economic Inclusion in Nigeria', United Nations Research Institute for Social Development, (November).

Mezzadra, S. (2008) La condizione postcoloniale. Storia e politica nel presente globale. Ombre Corte.

Mezzadra, S. and Neilson, B. (2013) 'Extraction, logistics, finance: Global crisis and the politics of operations', Radical Philosophy, 178: 8-18.

Mohandesi, S. (2013) 'Class consciousness or class composition?' Science and Society 77(1): $72-97$.

Moore, P. and Joyce S. (2019) Black box or hidden abode? The expansion and exposure of platform work managerialism. Review of International Political Economy.

Panzieri, R. (2020). Il lavoro e le macchine. Critica dell'uso capitalistico della tecnologia. A cura di Cengia, A. Ombre Corte: Verona.

Peticca-Harris, A., DeGama, N. and Ravishankar, M. N. (2020) 'Postcapitalist precarious work and those in the "drivers" seat: Exploring the motivations and lived experiences of Uber drivers in Canada', Organization, 27(1): 36-59. 
Pile, S. (2008) 'Where is the Subject? Geographical Imaginations and Spatializing Subjectivity', Subjectivity, 23(1): 206-218.

Pollio, A. (2019) 'Forefronts of the Sharing Economy: Uber in Cape Town', International Journal of Urban and Regional Research, 43(4): 760-775.

Poon, J. P. H. and Cheong, P. (2009) 'Objectivity, subjectivity, and intersubjectivity in economic geography: Evidence from the Internet and blogosphere', Annals of the Association of American Geographers, 99(3): 590-603.

Purcell, C., \& Brook, P. (2020). At Least I'm My Own Boss! Explaining Consent, Coercion and Resistance in Platform Work. Work, Employment and Society, 00(0): 1-16.

Read, J. (2009) 'A Genealogy of Homo-Economicus. Neoliberalism and the Production of Subjectivity', Foucault Studies (6): 25-36.

Reuters (2018) Kenya ride hailing taxi drivers reach deal for higher fares after week of strike. 11 July. Available at: https://af.reuters.com/article/kenyaNews/idAFL8N1U74CF

Ricaurte, P. (2019) 'Data Epistemologies, Coloniality of Power, and Resistance', Television and New Media. 20(4): 350-365.

Rizzo, M. and Atzeni, M. (2020) 'Workers’ Power in Resisting Precarity: Comparing Transport Workers in Buenos Aires and Dar es Salaam', Work, Employment and Society, 1-17.

Rogaly, B. (2009) 'Spaces of work and everyday life: Labour geographies and the agency of unorganised temporary migrant workers', Geography Compass, 3(6): 1975-1987.

Rosenblat, A. (2018). Uberland: How algorithms are rewriting the rules of work. Oakland, CA: University of California Press.

Sadowski, J. (2019) 'When data is capital: Datafication, accumulation, and extraction', Big Data \& Society, January-June: 1-12.

Sadowski, J. (2020) 'The Internet of Landlords: Digital Platforms and New Mechanisms of Rentier Capitalism', Antipode, 52(2): 562-580

Shapiro, A. (2018) 'Between autonomy and control: Strategies of arbitrage in the "on-demand" economy', New Media and Society, 20(8): 2954-2971. 
Shibata, S. (2019) 'Gig Work and the Discourse of Autonomy: Fictitious Freedom in Japan's Digital Economy', New Political Economy, 0(0): 1-17.

Srnicek, N., 2017. Platform capitalism. Cambridge: Polity Press.

Stanford, J. (2017) 'The resurgence of gig work: Historical and theoretical perspectives', Economic and Labour Relations Review, 28 (3): 382-401.

Strauss, K. (2020) 'Labour geography II: Being, knowledge and agency', Progress in Human Geography, 44(1): 150-159.

Tassinari, A. and Maccarrone, V. (2019) 'Riders on the Storm: Workplace Solidarity among Gig Economy Couriers in Italy and the UK', Work, Employment and Society, 1-20.

Toscano, A. (2009) Chronicles of Insurrection: Tronti, Negri and the Subject of Antagonism. Cosmos and History: The Journal of Natural and Social Philosophy, 5, 1. Available at: https://cosmosandhistory.org/index.php/journal/article/view/128/240

Tronti M (1966) Operai e capitale. Torino: Einaudi.

van Doorn, N. and Badger, A. (2020) 'Platform Capitalism's Hidden Abode: Producing Data Assets in the Gig Economy', Antipode, 52(5): 1475-1495.

Veen, A., Barratt, T. and Goods, C. (2019) 'Platform-Capital's “App-etite” for Control: A Labour Process Analysis of Food-Delivery Work in Australia', Work, Employment and Society, 1-19.

Yeung, K. (2017) “"Hypernudge”: Big Data as a mode of regulation by design', Information Communication and Society. Taylor \& Francis, 20(1): 118-136.

Wells, K. J., Attoh, K. and Cullen, D. (2020) ““Just-in-Place” labor: Driver organisingin the Uber workplace', Environment and Planning A, 0(0): 1-17.

Wood, A. J., Graham, M., Lehdonvirta, V., and Hjorth, I. (2018). Good Gig, Bad Gig: Autonomy and Algorithmic Control in the Global Gig Economy. Work, Employment and Society, 33(1): 56-75.

Wood, A. J., Lehdonvirta, V. and Graham, M. (2018) 'Workers of the Internet unite? Online freelancer organisation among remote gig economy workers in six Asian and African countries', New Technology, Work and Employment, 33(2): 95-112.

Wood, A. and Lehdonvirta, V. (2019) 'Platform Labour and Structured Antagonism: Understanding the Origins of Protest in the Gig Economy', SSRN Electronic Journal, 1-37. 
Woodcock, J. (2014) The Workers' Inquiry from Trotskyism to Operaismo: A Political Methodology for Investigating the Workplace. Ephemera 14(3): 493-513.

Woodcock, J. (2021) 'Towards a Digital Workerism: Workers' Inquiry, Methods, and Technologies', NanoEthics.

Woodcock, J., and Graham, M. (2019) The gig economy: a critical introduction. London: Polity.

Wright, S. (2002). Storming heaven: class composition and struggle in Italian autonomist Marxism. London: Pluto Press.

Wright, S. (2014) Revolution from Above? Money and Class Composition in Italian Operaismo. In van der Linden, M. and Roth, K. H. (eds.) Beyond Marx. Theorising the Global Labour Relations of the Twenty-First Century, 369-394, Leiden: Brill.

Zeleza, T. (1993) The strike movement in colonial Kenya: The era of the general strikes. Transafrican Journal of History, 22: 1-23

Zuboff, S. (2019) The Age of Surveillance Capitalism. The Fight for a Human Future at the New Frontier of Power. New York: Public Affairs.

Zwick, A. (2018) 'Welcome to the Gig Economy: neoliberal industrial relations and the case of Uber', GeoJournal. Springer Netherlands, 83(4): 679-691.

\footnotetext{
' In 2019, Taxify was rebranded Bolt.

ii At the time of the strike, according to figures obtained from Uber Kenya,.an estimate 5,000 drivers were active in Nairobi, while around a thousands operated in Mombasa.

iii Interview, leader DTAK, Nairobi, 14 August 2018

iv Through the article I use the original Italian denomination Operaismo/operaista.

${ }^{\vee}$ This and the other references to Panzieri's work in the article are translated by the author.

vi Interview with author, 12 September 2018

vii Ibid.

viii 18 out the 55 drivers of my samples reported to have slept in their vehicles at least 10 times over the past three months after a 14-hour working day.

ix interviews with author, July-August-September 2018.

* Interview with author, 19 July 2018

xi Interview with author, 1 August 2018

xii Interview with author, 1 August 2018

xiii Ibid.
} 
xiv interview with author, 4 July 2018

${ }^{x v}$ interview with author, 12 July 2018

xvi PUTON chairman Joe Ndiritu, interview with author, 15 August 2018

xvii Uber driver, interview with author, 27 July, 2018.

xviii Little Cab executive, interview with author, 28 September 2018.

xix Interview with author, 01 August, 2018.

${ }^{x x} \mathrm{~A}$ leader of an association representing 1500 taxi drivers calculated that " 19 of our members, all Uber and Taxify drivers, have died between 2016 and 2018"( Interview with author, 28 July 2018). 